\title{
The Translation Procedure of Tourism Terms in Garuda Indonesia Inflight Magazine: Colours
}

\author{
Annisa Putri Yunita ${ }^{1}$, Ketut Artawa ${ }^{2}$, Yana Qomariana ${ }^{3}$ \\ ${ }^{[1]}$ English Department, Faculty of Humanities, Udayana University \\ Denpasar, Bali \\ Email: annisaptri17@gmail.com@gmail.com \\ ${ }^{[2]}$ English Department, Faculty of Humanities, Udayana University \\ Denpasar, Bali \\ Email: ketut_artawa@unud.ac.id \\ ${ }^{[3]}$ English Department, Faculty of Humanities, Udayana University \\ Denpasar, Bali \\ Email: yana_qomariana@unud.ac.id
}

\begin{abstract}
This study discussed English-Indonesian articles in Colours Magazine that consist of tourism terms found in the article and translation procedures used by the translator in translating the articles. The data was taken from a magazine entitled Colours. The writer used three English-Indonesian tourism articles of April and December 2019 editions as research objects. The data was collected through library research and used qualitative and descriptive methods for data analysis. The theory of translation procedure by Newmark (1988) and Gui Lohmann and tourism terms by Lohman \& Netto (2017) were used to analyze the data. The result of this analysis shows that there are 7 types of tourism terms found, those are hospitality, entertainment, recreation, food and beverages, events, landscape, and authenticity in tourism and 7 procedures of translation found in this analysis namely, transference, naturalization, cultural equivalent, descriptive equivalent, reduction \& expansion, shift/transposition, and couplets.
\end{abstract}

Keywords: Translation, Tourism Terms, Procedure of translation

\section{INTRODUCTION}

In Indonesia, translation has a very important role. This phenomenon occurred since only a little information is available in Bahasa Indonesia, but it is presented in foreign languages, especially in English. (Choliludin, 2005, p.1). Defined by Newmark (1988) that translation is "the process of rendering the meaning of a text into another language in a way that the author intended the text" (Newmark, 1998, p. 5). In addition, Bell (1991) states that translation is the replacement of a representation of a text in a second language (1991, p. 6). Another definition by Catford (1974), said that "translation is the replacement of textual material in one language (source language) by equivalent textual material in another language (target language)".

The use of languages, both Indonesian and foreign languages is very important in the tourism industry. This can be shown in the procurement of printed materials regarding tourist objects in Indonesia. For the consumption of foreign tourists, a writer with foreign languages is needed, especially with good English, or at least the tourism texts that have been printed in Indonesian can be translated and printed into English well. Regarding this, translation plays a crucial role for people to get information that is written in English. In tourism text or article, there are a lot of tourism terms that occurred and people need to know. Tourism is characterized as a well-defined collection of relationships, services, and facilities that are created as a result of specific human movements, as quoted from Cuervo (1967, p. 29).

In doing a translation, some procedures are used. The procedure means a particular method of doing something. Newmark (1998) states that "Translation procedures are used for sentences and smaller units of language". To get a good translation, the translator has to transfer the meaning of the text by using some different procedures.

Based on the phenomenon above, it has been clear that having a good understanding of the theories, especially the procedures of translation is very important to have the best 
quality in the result of translation projects. In terms of giving beneficial data, this study focused on the investigation of translation procedures applied in the translation of tourism terms in the magazine, especially in the inflight magazine Colours by Garuda Indonesia Airline.

\section{Problems of the Study}

Based on the background above, two problems can be formulated as follows:

a. What types of tourism terms are found in Colours Magazine's article?

b. How are translation procedures applied in the translation of tourism terms in Colours Magazine's article?

\section{Aims of the Study}

Based on the problems of the study above, the aims of the study are formulated as follows:

a. To identify the tourism terms found in Colours Magazine's Colours

b. To describe the translation procedures applied in the translation of tourism terms in Colours Magazine's article.

\section{ReSEARCh Method}

The research method covers data source, method and technique of collecting data, method, and technique of analyzing data, and method and technique of presenting analysis.

\section{Data Source}

The data source of this study is primary data taken from the magazine entitled Colours wrote by Garuda Indonesia Airline. This magazine was published monthly by PT Garuda Indonesia. The documents are tourism texts and the translations in Garuda Indonesia's Inflight Magazine Colours. In this research, the writer used three tourism articles of April and December 2019 editions which were written in Indonesian and English as research objects.

\section{Method and Technique of Collecting Data}

The method of collecting data in this study used the documentation method, which means the data was collected through reading and taking notes. There are some techniques for collecting data. The first step was reading the magazine in both versions, and then check all the words, phrases, or clauses that were categorized as tourism terms. After categorizing the tourism terms, then identifying the tourism terms that belong to the procedures of translation. Then, make notes based on the collected data.
Method and Technique of Analyzing Data

The data were analyzed by using descriptive and qualitative methods. There are some techniques for analyzing data. In the first technique, the tourism terms were collected and classified into types of translation procedures. Second, the data was analyzed and described to identify how the translation procedures applied in the translation of tourism terms. Then, the results of the analysis were written in the form of a paragraph. This study used the descriptive method in presenting data related to the subject of this study. All of the data of this study were presented in sentences.

\section{Method and Technique of Presenting Data}

This study used the descriptive method in presenting data related to the subject of this study. All of the data of this study were presented in sentences. The techniques of presenting data are; after all of the data were analyzed, then the data were presented descriptively by using words and sentences.

\section{Results AND Discussion}

The analysis discussed the translation procedures applied in the translation of tourism terms in the magazine.

\section{a. Transference}

SL: Jakarta's best brunch is served at Sugar \& Spice that features international cuisines from five continents through six show kitchens. (CM, December 2019: 46)

TL: Nikmati brunch terbaik di Jakarta dengan variasi santapan internasional dari lima benua dengan enam show kitchens. (CM, December 2019: 46)

In the data above, the term brunch in the article entitled "Travel Trends" is considered as a food and beverages term. Based on the Dictionary of Travel, Tourism \& Hospitality, brunch is "a meal served between normal breakfast and lunchtimes and replacing breakfast and lunch". The word brunch was translated into brunch in the target language. The translator only used the same word from the source language because there is no equivalent word in the target language.

\section{b. Naturalization}

SL: In the hot midday sun, people cooled down at one of the many indoor shows like 'Oscar's Grouchmas' or sought shelter at the cafe dan canteen. (CM, April 2019: 73)

TL: Di tengah terik matahari siang, pengunjung pun mulai meneduh dari panas dengan memasuki sejumlah pertunjukan yang diadakan dalam ruangan, seperti 'Oscar's Grouchmas' atau masuk ke kafe dan kantin. (CM, April 2019: 77) 
In the data above, the term canteen in the article entitled "A Family Holiday in Asia" is categorized in food and beverages terms. According to the Dictionary of Leisure, Travel, and Tourism, it refers to "a place in a factory, office, etc. where food and meals are sold, often at a lower price than usual" the word in the source language canteen was translated into kantin in the target language. There is conversion in letter ' $\mathrm{c}$ ' which changes into ' $\mathrm{k}$ ' and also the letters ' $e$ ' changes into ' $i$ '. The word canteen in the source language is pronounced as $/ \mathrm{kæn}$ 'ti:n/, while the word kantin is pronounced as $/ \mathrm{kantin} /$ in the target language. The naturalization could be seen since the pronunciation of those words are not completely different.

\section{c. Cultural Equivalent}

SL: If rides aren't your thing, there are plenty of street performances to enjoy. (CM, April 2019: 73)

TL: Jika anda tidak terlalu antusias dengan wahana permainan, tersedia pula ragam atraksi keliling yang bisa dinikmati. (CM, April 2019: 77)

The data above, the term street performance in the article entitled "A Family Holiday in Asia" is categorized in entertainment terms. Simpson (2011) states that the term street performance refers to a group of activities in which musicians or non-musicians perform in the street to elicit donations from passersby. The phrase street performance in source language was translated into atraksi keliling in the target language by using a cultural equivalent procedure. The translator used the closest meaning or the equivalent of street performances in the target language culture. In the target language, there's a cultural term atraksi keliling which has the same meaning as street performance.

\section{d. Descriptive Equivalent}

SL: In the hot midday sun, people cooled down at one of the many indoor shows. (CM, April 2019: 73)

TL: Di tengah terik matahari siang, pengunjung pun mulai meneduh dari panas dengan memasuki sejumlah pertunjukan yang diadakan dalam ruangan. (CM, April 2019: 77)

The article entitled "A Family Holiday in Asia", shows the descriptive equivalent procedure. It was applied in the phrase indoor show and the translation was pertunjukan yang diadakan dalam ruangan. The phrase indoor show means pertunjukan dalam ruangan in the target language. The phrase pertunjukan dalam ruangan that consists of three words is translated into pertunjukan yang diadakan dalam ruangan, which consists of five words. The translation describes the meaning of indoor show into several words to make the readers know what the indoor show is.

\section{e. Reduction}

SL: Even more remarkable is the sight of people iceskating under the stars in a specially constructed rink in The Meadow. (CM, December 2019: 82)
TL: Lebih menariknya lagi, di The Meadow, orang-orang berseluncur di arena ice-skating di bawah taburan bintang. (CM, December 2019: 85)

In the article entitled "Christmas in Singapore", the data above is considered in recreation term. The phrase ice-skating in the source language was translated into berseluncur in the target language. In the data above, the word "ice" in the phrase ice-skating was not translated. Based on the context, "specially constructed rink" was translated into "arena ice-skating". It can be concluded that the word ice was not translated because the translator might do it to omit unimportant parts since the reader still gets the meaning.

\section{f. Expansion}

SL: There's also a LEGO-themed water park and even a hotel with LEGO décor. (CM, April 2019: 74)

TL: Ada pula taman permainan air bertema LEGO dan bahkan hotel dengan desain interior bertema LEGO. (CM, April 2019: 78)

In the data above the phrase in the article entitled "A Family Holiday in Asia" is categorized as an entertainment term. The expansion procedure was applied in the fragment water park and the translation was taman permainan air. The phrase water park means taman air in the target language. There is additional information 'permainan' which is placed in the middle of the word 'taman' and 'air'. In the target language, it could give new information that the phrase water park is a theme park which consists of some rides or permainan.

\section{CONCLUSION}

Based on the analysis of the previous chapter, it can be concluded that some procedures are applied in the English-Indonesian translation of tourism terms in Colours Magazine's articles. There are three types of tourism terms that occurred in the articles. Those are entertainment, recreation, food, and beverages.

There are 18 procedures based on Peter Newmark's book entitled A Textbook of Translation (1988) and 4 of them are found as procedures applied in the magazine, are; Transference, Naturalization, Cultural Equivalent, and Reduction and Expansion. The procedures are mostly found in the translation of words or phrases from the source language into the target language. Translation procedures found based on the analysis cause some source language words or phrases to be clearer, understandable, and adjusted towards the culture of the target language. There is no change of the message or the meaning given by the text, although some procedures are applied or used from the source language into the target language. 


\section{REFERENCES}

[1] Bell. (1991). Translation and Translating Theory and Practice. Longman.

[2] Black, A. \& C., \& Staff, U. B. P. (2009). Dictionary of Leisure, Travel, and Tourism. Bloomsbury Publishing UK.

https://public.ebookcentral.proquest.com/choice/public fullrecord.aspx? $\mathrm{p}=4948094$

[3] Catford, J. C. (1974). A Linguistic Theory on Translation. Oxford University Press.

[4] Choliludin. (2005). The Technique of Making Idiomatic Translation. Kesaint Blanc.

[5] Cuervo, R. (1967). El Turismo como Medio de Communicacion Humana. Departmento de Turismo del Gobierno de Mexico.

[6] Garuda, I. (2019a, December). Colors Magazine. 1, 46, $73,74,77$.

[7] Garuda, I. (2019b, December). Colors Magazine. 1, 46.

[8] Harris, R., \& Howard, J. (1996). Dictionary of travel, tourism, and hospitality terms. Hospitality Press Pty Ltd.; CABDirect. https://www.cabdirect.org/cabdirect/abstract/19961802 725

[9] Japhari, S. (2019). Translation of the Book Titled 'Authentication of Hadith: Redefining the Criteria' From English Into Swahili: An Analysis of Translation Procedures. SSRN Electronic Journal. https://doi.org/10.2139/ssrn.3441606

[10] Kamil. (2014). An Analysis of English-Indonesian Translation Procedures on Twitter Web pages. The Indonesia University of Education.

[11]Lohmann, G., \& Panosso Netto, A. (2017). Tourism theory: Concepts, models, and systems. CAB International.

[12] Mashaddy, Pourgalavi, \& Fatollahi. (2005). Newmark's Procedures in Persian Translation of Golding's Lord of the Flies.

[13] Munday, J. (2010). Introducing translation studies: Theories and applications. Taylor \& Francis e-Library. http://site.ebrary.com/id/10370235

[14] Newmark, P. (1988). A Textbook of Translation. Prentice-Hall.

[15] Satriadi. (2014). An Analysis of Translating Procedures on Sony Ericsson with Walkman Series Start-up Guide. Jakarta.

[16] Simpson, P. (2011). Street Performance and the City Public Space, Sociality, and Intervening in the Everyday. Space and Culture, 14, 415-430. https://doi.org/10.1177/1206331211412270

[17] Smith, \& Godbey. (1991). Annals of Tourism Research 18 .
[18] Trinity. (2019, December). Colors Magazine. 1, 82, 85. [19] Warhamni, U. (2010). An Analysis of EnglishIndonesian Translation Procedures on Twilight Novel. State Islamic University. 